\title{
ANALISA PENGURUSAN PROSES KLAIM ASURANSI KECELAKAAN KAPAL YANG MENABRAK BREAKWATER, STUDI KASUS BG. MARITIME LADY DI TELUK PENYU CILACAP
}

\author{
Winarno $^{\mathrm{a}}$, Wim Benhard Manurung ${ }^{\mathrm{b}}$ \\ ${ }^{a}$ Program Studi Tatalaksana Angkutan Laut dan Kepelabuhanan (TALK) PIP Semarang \\ ${ }^{\mathrm{b}}$ Program Studi Tatalaksana Angkutan Laut dan Kepelabuhanan (TALK) PIP Semarang \\ winarno@pip-semarang.ac.id \\ wimbenhard52@gmail.com
}

\begin{abstract}
The shipping business feels the importance of the risk of financial responsibility arising from the operation of ships, the obligation of ship owners/operators must be responsible for the safety of passengers and the cargo they carry in the event of an accident causing injury or causing loss to passengers, as well as loss/damage to transported cargo and losses to third parties, namely by transferring risk to other parties where the other party as the recipient of the risk and being able to manage the risk are insurance companies. In this case the ship owner and operator can guarantee the risks of responsibility that arise with $P \& I$ Club insurance. In this case the researcher uses a qualitative descriptive writing method to describe and describe the object under research. In addition, this research also uses observation, interviews and literature.

From an analysis of the matter he added group of researchers from came to the conclusion that the process of and settlement of the insurance claim had been completed and was although there have been a obstacles faced. Constraints faced in the process and settlement of claims are complete claims documents, selection of contracting companies, and socio-economic conditions and weather. The efforts made in reducing the are, research the ownership documents contractor in accordance the classification of PT. Pertamina as well as persuasive approach it cooperates with BMKG case and supervision from PT. Pertamina division marine in repairing process.
\end{abstract}

\section{Keywords: Claims, Insurance, Ships collision}

\section{PENDAHULUAN}

Kecelakaan kapal di Indonesia sering terjadi dengan berbagai sebab mulai dari faktor kelalaian manusia (human error factor), faktor teknis (technical factor) maupun faktor alam (force majeur factor) dan faktor lain (other factor). Banyaknya kasus kecelakaan atau insiden kapal yang terjadi dapat menimbulkan risiko berupa kerugian, kerusakan dan kehilangan bagi kepemilikan kapal (owning of the ship) dan pihak ketiga sebagai pemilik barang. Untuk memperkecil risiko yang mungkin timbul maka ketentuan peraturan perundangundangan mengatur dengan sangat jelas tentang kewajiban pengangkut sebagai pemilik atau operator kapal untuk bertanggung jawab atas insiden atau kecelakaan. Cara untuk mengelola risiko tersebut, adanya jaminan asuransi atau bekerja sama dengan perusahaan asuransi yang memiliki dasar hukum yang sah. Dengan penutupan asuransi kecelakaan kapal atau kerugian laut sebagaimana diatur dalam Undang-Undang No. 17 Tahun 2008 tentang Pelayaran mengatur pengangkut, yaitu pemilik atau operator kapal dalam pengoperasian kapalnya. 


\section{Winarno $^{\text {a }}$, Wim Benhard Manurung ${ }^{\mathrm{b}}$}

\section{Undang-Undang Nomor 17 Tahun} 2008 Tentang Pelayaran mengatur kewajiban pengangkut yaitu pemilik atau operator kapal yaitu dalam pasal 40 dan pasal 41, sebagai berikut:

\section{A. Pasal 40}

1. Perusahaan angkutan di perairan bertangggung jawab terhadap keselamatan dan keamanan penumpang dan/atau barang yang diangkutnya.

2. Perusahaan angkutan di perairan bertanggung jawab terhadap muatan kapal sesuai dengan jenis dan jumlah yang dinyatakan dalam dokumen muatan dan/atau perjanjian atau kontrak pengangkutan yang telah disepakati.

B. Pasal 41

1. Tanggung jawab sebagaimana dimaksud dalam Pasal 40 dapat ditimbulkan sebagai akibat pengoperasian kapal, berupa:
a. Kematian atau lukanya penumpang yang diangkut.
b. Musnah, hilang, atau rusaknya barang yang diangkut.
c. Keterlambatan angkutan penumpang dan/atau barang yang diangkut.
d. Kerugian pihak ketiga.

2. Jika dapat membuktikan bahwa kerugian sebagaimana dimaksud pada ayat (1) huruf $b$, huruf $c$, dan huruf $\mathrm{d}$ bukan disebabkan oleh kesalahannya, perusahaan angkutan di perairan dapat dibebaskan sebagian atau seluruh tanggung jawabnya.

3. Perusahaan angkutan di perairan wajib mengasuransikan tanggung jawabnya sebagaimana dimaksud pada ayat (1) dan melaksanakan asuransi perlindungan dasar penumpang umum sesuai dengan ketentuan peraturan perundangundangan.

PT. Salam Bahagia sebagai pemilik/operator kapal mengasuransikan kapalnya kepada pihak asuransi The Shipowners Insurance yang terdapat pada $\mathrm{P} \&$ I Club. P \& I Club merupakan asosiasi bersama yang dibentuk oleh para pemilik kapal untuk membela kepentingannya dalam usaha menghadapi tuntutan klaim ganti rugi terhadap pihak ketiga karena tidak bisa ditutup (cover) semua oleh asuransi. Berikut ini adalah rumusan yang dikemukakan oleh peneliti:

1. Bagaimana proses pengajuan klaim asuransi kecelakaan kapal BG. Maritime Lady yang menabrak breakwater Teluk Penyu Cilacap?

2. Kendala apa saja yang terjadi dalam proses klaim asuransi kecelakaan kapal BG. Maritime Lady yang menabrak breakwater Teluk Penyu Cilacap?

3. Upaya apa saja yang dilakukan utnuk mengatasi kendala yang terjadi dalam proses klaim asuransi kecelakaan kapal BG. Maritime Lady yang menabrak breakwater di Teluk Penyu Cilacap?

\section{BAHAN DAN METODE PENELITIAN}

Dalam penelitian ini menggunakan metode deskriptif kualitatif untuk menggambarkan dan menguraikan objek yang diteliti. Menurut Deny Hamdani dalam buku pengantar metodologi penelitian panduan penulisan tugas akhir (2010: 51) mengemukakan bahwa metode deskriptif adalah jenis penelitian yang memberikan uraian tentang permasalahan atau suatu keadaan tertentu tanpa ada perlakuan terhadap objek yang diteliti. Sugiyono (2016: 9), menjelaskan bahwa penelitian kualitatif merupakan metode penelitian yang digunakan untuk meneliti objek ilmiah (sebagai lawannya adalah eksperimen) dimana peneliti adalah instrumen kunci, pengambilan sampel sumber data dilakukan secara purposive dan snowball, teknik pengumpulan dengan triangulasi, analisis data bersifat induktif atau kualitatif, dan hasil penelitian lebih menekankan makna dari pada generalisasi. Dalam pengelolahan data ini, peneliti mengelola sendiri data hasil penelitian yang berasal dari subjek penelitian. Data ini diperoleh dari hasil observasi langsung dan wawancara terhadap aktifitas kegiatan PT. Spicaputra Sarana (koresponden) dan 
PT. Boyd Marine Consultants (Surveyor) dalam pelaksanaan proses dan penyelesaian klaim asuransi kecelakaan kapal BG. Maritime Lady yang menabrak dermaga di Teluk Penyu Cilacap.

Lokasi penelitian terletak di Kantor PT. Spicaputra Sarana dan PT. Boyd Marine Consultants yang beralamatkan di Wisma PMI $6^{\text {th }}$ Floor, Jalan Wijaya No. 63, Kebayoran Baru, Jakarta Selatan 12170 dan Breakwater Pelabuhan Teluk Penyu Cilacap.

\section{HASIL DAN PEMBAHASAN}

Berdasarkan hasil pengamatan pada saat melakukan penelitian tentang bagaimana proses klaim asuransi kecelakaan kapal BG. Maritime Lady yang menabrak breakwater pelabuhan Teluk Penyu Cilacap, dan kendala apa saja yang dihadapi serta bagaimana upaya yang dilakukan untuk mengatasi kendalakendala yang dihadapi dalam proses klaim tersebut. TB. SMS Vanda yang mengandeng BG. Maritime Lady milik perusahaan pelayaran PT. Salam Bahagia berlabuh dan lego jangkar pada posisi 07 $44.557^{\prime}$ S $109^{\circ} 06.187^{\prime}$ E yang menunggu jadwal sandar. Kapal BG. Maritime Lady terkait dengan kasus tubrukan atau kecelakaan kapal yang terjadi pada tanggal 04 Agustus 2017 Pukul 01.35 di Perairan Teluk Penyu Cilacap, Jawa Tengah. Pada tanggal 04 Agustus 2017 cuaca semakin buruk dan kondisi laut berombak dengan tinggi gelombang sekitar 3 meter serta kecepatan angin 20 knot. menyebabkan tali towing atau penarik itu terputus dan BG. Maritime Lady hanyut atau larat serta tidak terkendali dan menabrak atau menghantam pemecah gelombang (breakwater) kemudian kandas di pantai Teluk Penyu Cilacap (berita acara terlampir). Sehingga menimbulkan tuntutan dari pihak ketiga, yaitu:
A. Menabrak dan mengakibatkan kerusakan pada pemecah gelombang (breakwater) di Teluk Penyu Cilacap.

B. Menyebabkan kerusakaan pada daerah pantai dikarenakan daerah tersebut digunakan sebagai tempat pariwisata di Teluk Penyu Cilacap.

Berdasarkan hasil pengamatan pada saat melakukan penelitian di PT. Spicaputra Sarana (SPICA Services Indonesia) dan PT. Boyd Marine Consultants Indonesia, semua masalah berkaitan dengan proses klaim asuransi kecelakaan kapal BG. Maritime Lady.

1. Bagaimana proses klaim asuransi kecelakaan kapal BG. Maritime Lady yang menabrak breakwater Teluk Penyu Cilacap

Berdasarkan hasil penelitian pada PT. Spicaputra Sarana (SPICA Services) Indonesia dan PT. Boyd Marine Consultants Indonesia yang dilakukan oleh peneliti. Peneliti mendapatkan data mengenai proses klaim asuransi kecelakaan kapal secara detail, sebagai berikut:

a. Tahapan Laporan

Tindakan pertama yang dilakukan oleh pemilik kapal yakni PT. Salam Bahagia selaku pemilik TB. SMS Vanda dan BG. Maritime Lady melakukan tahapan laporan atau pemberitahuan pertama tentang adanya kejadian atau kecelakaan (initial notice/notice of accident) kepada P \& I Club (The Shipowners Insurance) dikarenakan mengalami kejadian yang mungkin berpotensi menimbulkan kerugian bagi pihak lain yang terkait perjanjian dengan member selaku pemilik atau operator kapal dikarenakan timbulnya tuntutan hukum dari pihak ketiga (tubrukan dengan kapal lain atau dengan fasilitas pelabuhan) karena kesalahan pihak kapal dan melaporkan 


\section{Winarno $^{\text {a }}$, Wim Benhard Manurung ${ }^{\mathrm{b}}$}

kepada pihak koresponden (local correspondent) dengan bentuk laporan berupa berita acara beserta foto-foto kerusakaan yang terjadi.

b. Penunjukkan Koresponden (local correspondent)

Untuk membantu member (operator atau pemilik kapal) dalam pengurusan klaim, pihak $\mathrm{P}$ \& I Club (The Shipowners Insurance) menunjuk koresponden (local correspondent) sebagai perwakilan $\mathrm{P} \& \mathrm{I}$ Club dalam pengurusan klaim. P \& I Club akan menunjuk koresponden (local correspondent) melalui telepon dan email yang disertakan dengan laporan dari member. Dalam penelitian ini P \& I Club menunjuk PT. Spicaputra Sarana (SPICA Services) Indonesia sebagai koresponden (local correspondent) sesuai data yang terlampir serta dikarenakan member (PT. Salam Bahagia) merupakan member asuransi operator kapal (The Shipowners Insurance) dengan sertifikat asuransi yang dimiliki (certificate of entry) yang menyatakan bahwa kapal TB. SMS Vanda dan BG. Maritime Lady merupakan member dari asuransi tersebut. Berikut terlampir data penyelesaian insiden atau case yang ditangani oleh PT. Spicaputra Sarana (SPICA Services) Indonesia dari Tahun 2018 sesuai dengan waktu peneliti dalam melakukan penelitian pada perusahaan tersebut.
Tabel Jumlah Insiden atau Case Tahun 2017-2018

\begin{tabular}{|l|l|l|l|l|}
\hline \multirow{2}{*}{ NO } & \multicolumn{2}{|c|}{$\begin{array}{c}\text { PT. Spicaputra } \\
\text { Sarana (SPICA } \\
\text { Services) }\end{array}$} & \multicolumn{2}{|c|}{$\begin{array}{c}\text { PT. Boyd Marine } \\
\text { Consultants }\end{array}$} \\
\cline { 2 - 5 } & $\begin{array}{l}\text { Closed } \\
\text { File }\end{array}$ & $\begin{array}{l}\text { Running } \\
\text { File }\end{array}$ & $\begin{array}{l}\text { Closed } \\
\text { File }\end{array}$ & $\begin{array}{l}\text { Running } \\
\text { File }\end{array}$ \\
\hline $\mathbf{2 0 1 7}$ & 1140 & 168 & 373 & 72 \\
\hline $\mathbf{2 0 1 8}$ & 824 & 166 & 392 & 70 \\
\hline Jumlah & 1964 & 334 & 765 & 142 \\
\hline
\end{tabular}

Sumber : PT. Spicaputra Sarana (SPICA Services) dan PT. Boyd Marine Consultants

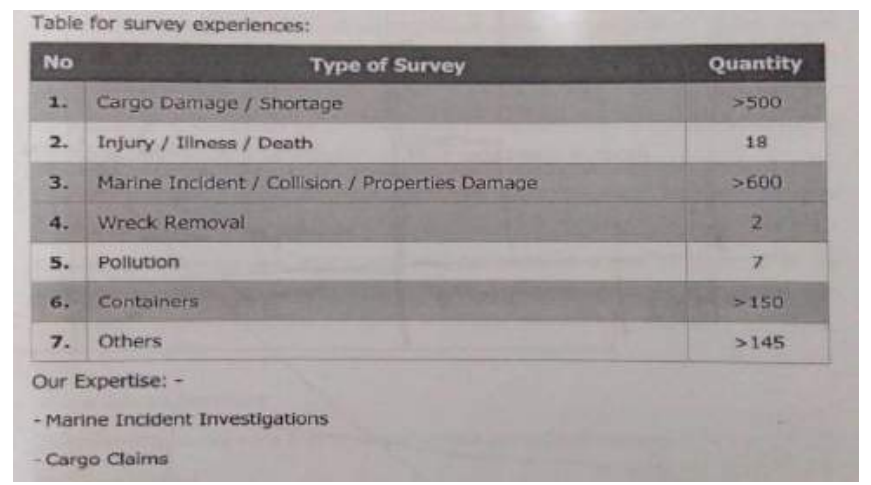

Gambar Jenis Survei

Sumber : PT. Boyd Marine Consultants Indonesia

c. Penunjukkan independen surveyor, lawyer dan kontraktor Setelah penunjukkan koresponden (local correspondent) dilakukan maka koresponden akan mengirimkan perwakilannya (independen surveyor) atau lawyer (jika diperlukan) dan kontraktor (jika diperlukan) untuk melakukan investigasi dan wawancara kepada member atau orang yang diperkerjakan oleh member yang dinilai mengetahui kejadian 
tersebut, disamping itu juga perlu mendapat perhatian adalah bahwa tanpa persetujuan Club dan koresponden (local correspondent), member sama sekali tidak dibenarkan untuk mengakui segala kejadian yang terjadi adalah tanggung jawab atau kesalahannya (never admit liability). PT. Spicaputra Sarana (SPICA Service) Indonesia menunjuk perusahaan independen surveyor yaitu PT. Boyd Marine Consultants Indonesia.

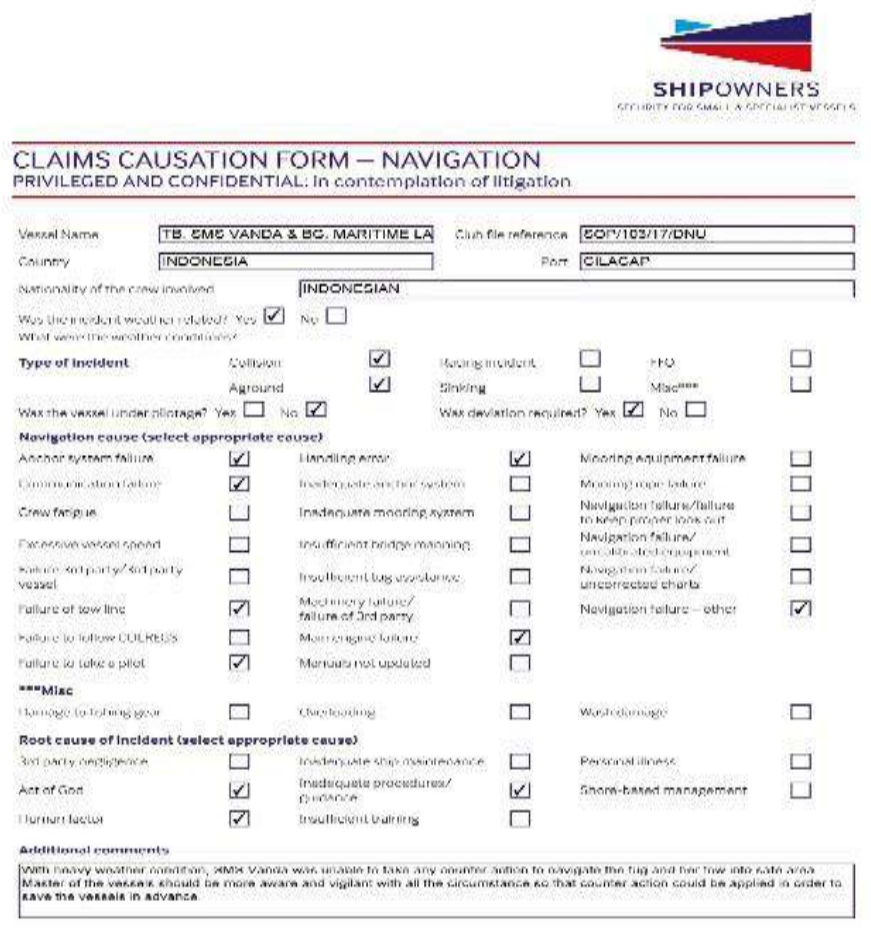

Gambar Claims Causation Form

Sumber : P \& I Club (The Shipowner's Insurance)

Berdasarkan wawancara yang dilakukan dengan pihak koresponden (local correspondent), peneliti mendapatkan informasi sebagai berikut:

Dalam penunjukkan independen surveyor, lawyer dan kontraktor (ahli) yang dilakukan yaitu:
1) Tanpa mengesampingkan ketentuan yang berlaku khusus tentang menunjukkan surveyor, lawyer dan kontraktor (ahli) kapanpun $\mathrm{P}$ \& I Club sehubungan dengan pengajuan klaim yang ditunjuk kepada member.

2) Penunjukkan surveyor, lawyer, dan kontraktor (ahli) untuk kepentingan dan atas nama member harus selalu memperhatikan asas prinsip bahwa penunjukkan tersebut tidak akan menimbulkan konflik, maka keadaan tersebut menjadikan dasar untuk membatalkan salah satu dari penunjukkan.

Pihak koresponden (local corresponeden) menunjuk perusahaan kontraktor untuk membantu proses perbaikan pemecah gelombang (breakwater) yang telah rusak. Penunjukkan tersebut dalam penelitian ini membutuhkan waktu dikarenakan harus sesuai dengan klasifikasi dan kriteria dari PT. Pertamina sebagai pembangun pertama pemecah gelombang (breakwater) tersebut. Dengan pemilihan yang sesuai klasifikasi dan kriteria PT. Pertamina maka terpilihlah PT. Gillar Jaya sebagai kontraktor perbaikan breakwater Teluk Penyu Cilacap. peranan surveyor yang telah ditunjuk tepat dan sesuai klasifikasi dari club sangat penting dalam membantu menangani insiden atau case kecelakaan kapal walaupun mengalami kendala waktu dalam menunjuk perusahaan kontraktor (ahli).

d. Pelaksanaan Survei

Survei dilaksanakan oleh surveyor yang telah ditunjuk untuk membantu proses investigasi dan mencari informasi mengenai insiden atau case yang terjadi. Investigasi dilakukan pada 13 


\section{Winarno $^{\mathrm{a}}$, Wim Benhard Manurung ${ }^{\mathrm{b}}$}

Agustus 2017 sampai 04 April 2018 oleh surveyor dari PT. Boyd Marine Consultants Indonesia yang telah ditunjuk pihak koresponden (local correspondent) di tempat kejadian yaitu breakwater Teluk Penyu Cilacap seperti pada gambar.
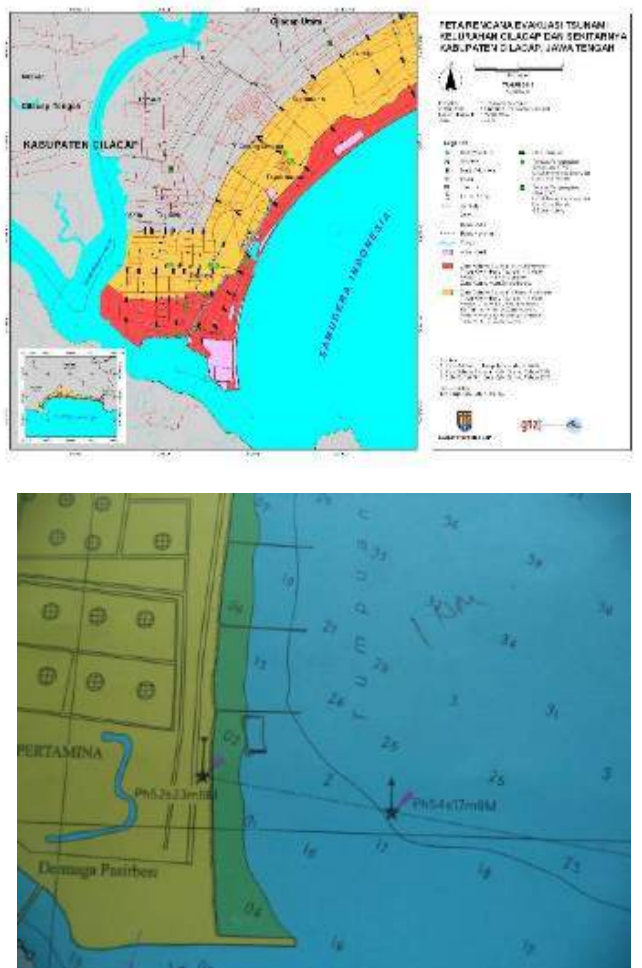

Gambar Posisi Breakwater Teluk Penyu Cilacap

Sumber :

http://smeksas.blogspot.com/2016/08/denganprovinsi-jawa-barat-cilacap.html

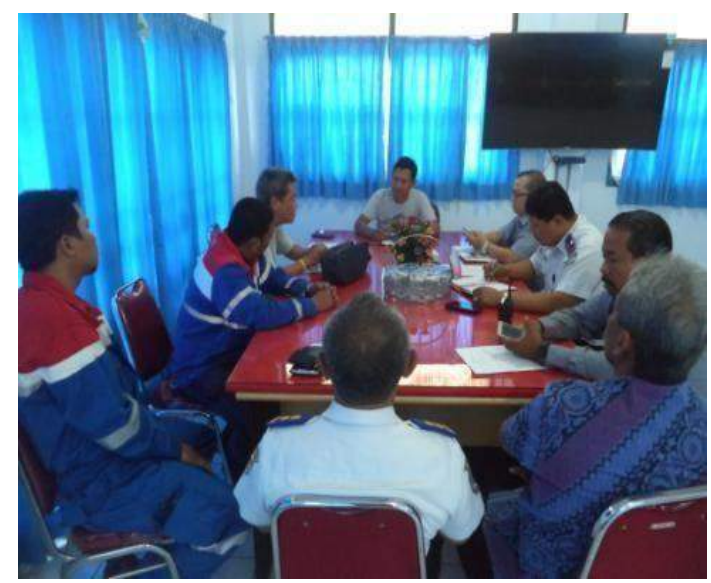

Gambar Meeting proses perbaikan breakwater Sumber : Dokumen pribadi

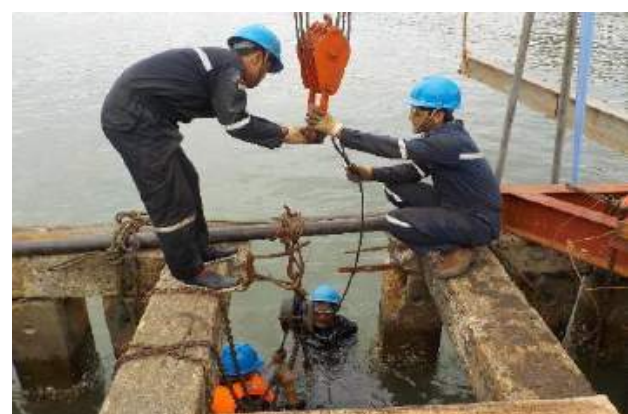

Gambar Pengukuran tiang breakwater Sumber : Dokumen pribadi

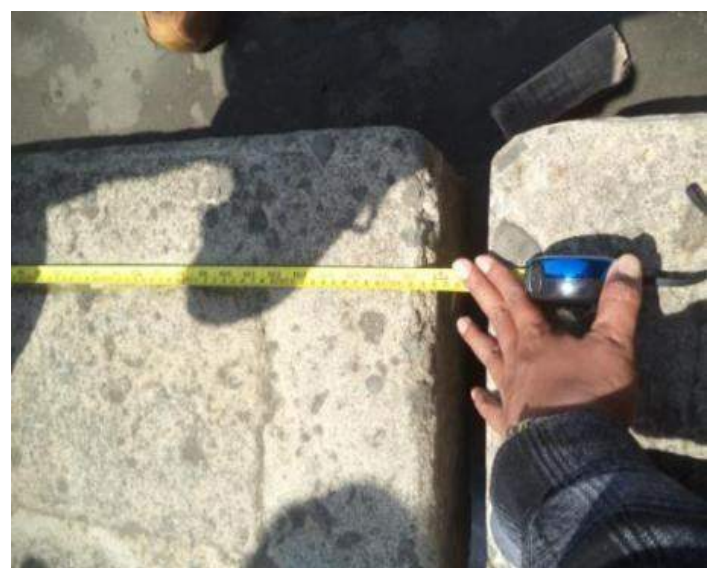

Gambar Pengangkatan tiang breakwater yang rusak

Sumber : Dokumen pribadi

Investigasi atau survei dilakukan sampai keadaan pemecah gelombang (breakwater) tersebut telah selesai diperbaiki sesuai dengan kesepakatan dan klasifikasi dari PT. Pertamina. Investigasi dilakukan oleh PT. Boyd Marine Consultants Indonesia yang telah ditunjuk PT. Spicaputra Sarana (SPICA Services) Indonesia. PT. Boyd Marine Consultants Indonesia melakukan investigasi atau survei sesuai SOP insiden atau case yang ditangani serta perbaikan breakwater telah selesai. 
Tabel SOP Survei Investigasi

Sumber : PT. Boyd Marine Consultants Indonesia

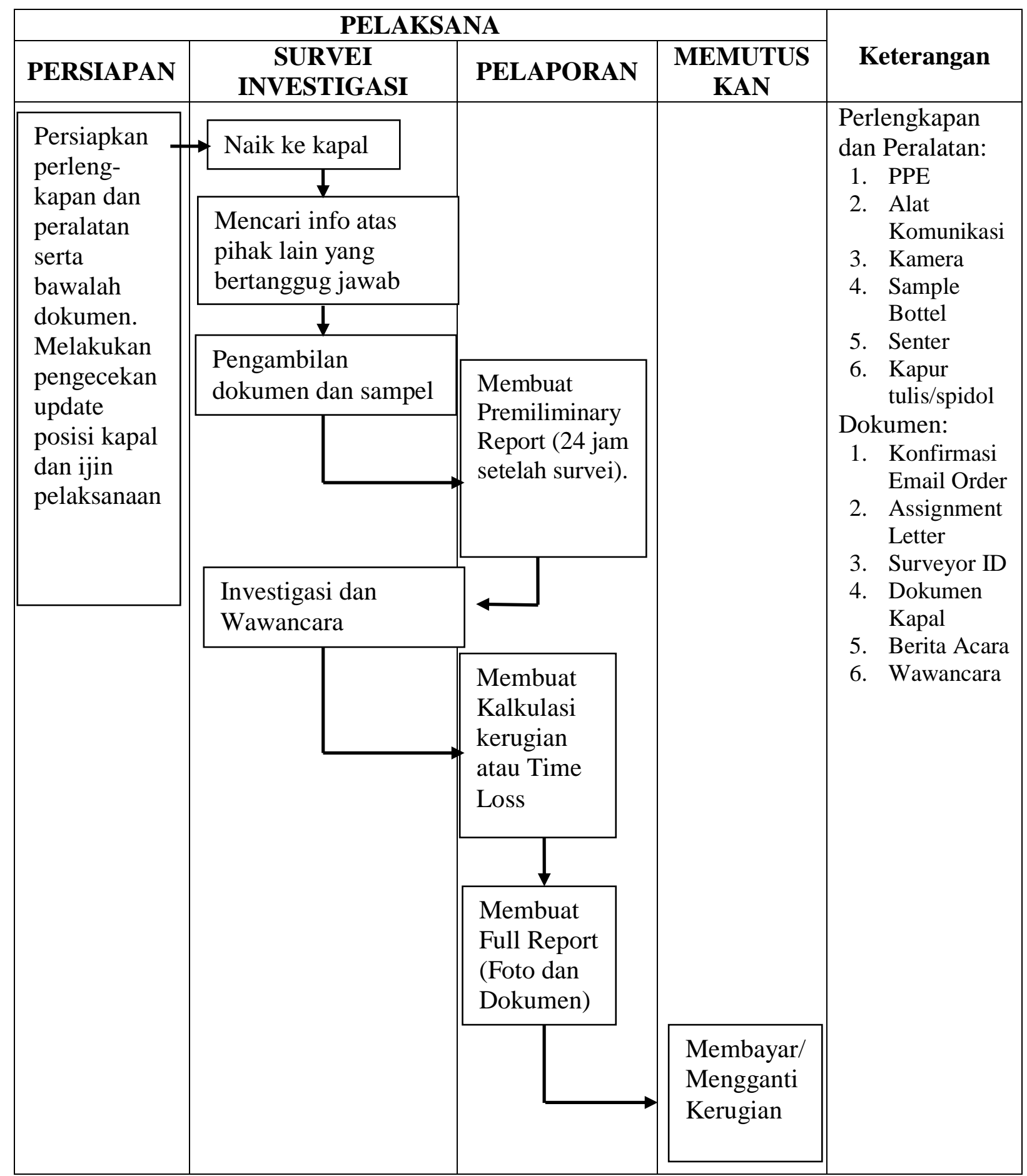

Berikut ini tiga masalah yang dihadapi dalam proses klaim asuransi kecelakaan kapal BG. Maritime Lady yang menabrak breakwater Teluk Penyu Cilacap, yaitu:

1. Persyaratan kelengkapan dokumen klaim yang tidak lengkap
Kelengkapan dokumen tersebut yaitu tentang kepemilikan asli dan data kontruksi pemecah gelombang (breakwater) Teluk Penyu Cilacap. Dalam proses dan penyelesaian klaim pada insiden atau case tersebut mengalami kendala mengenai 


\section{Winarno $^{a}$, Wim Benhard Manurung ${ }^{\mathrm{b}}$}

persyaratan kelengkapan dokumen klaim. Kelengkapan dokumen tersebut yaitu tentang kepemilikan asli pemecah gelombang (breakwater) Teluk Penyu Cilacap. Pihak asuransi (club) tidak akan memperoses atau menyelesaikan klaim atas insiden atau case tersebut, apabila kepemilikan pemecah gelombang (breakwater) Teluk Penyu Cilacap tersebut tidak jelas. Kepastian kepemilikan tersebut digunakan agar tidak adanya pihak lain yang akan mengklaim kembali atau mempermasalahkan serta mengambil kesempatan dalam insiden atau case ini. Berdasarkan kesepakatan bersama dalam meeting yang dilaksanakan bahwa PT. Pertamina meminta operator kapal untuk memperbaiki breakwater sesuai struktur dan fungsinya. Didalam penelitian ini berdasarkan pertemuan atau meeting ketiga dan keempat yang dihadiri oleh pihak operator kapal, pihak P \& I Club, PT. Pertamina, Surveyor, PT. Gillar Jaya bahwa PT. Pertamina meminta kepada pihak operator kapal untuk memperbaiki breakwater sesuai struktur dan fungsinya kembali berdasarkan klasifikasi dan penelitian pihak Pertamina Kelautan IV Divisi Teknik sehingga perbaikan breakwater dapat dilaksanakan.

2. Pemilihan kontraktor dalam perbaikan pemecah gelombang (breakwater)

Dalam insiden atau case ini mengakibatkan kerusakan pada pemecah gelombang (breakwater) yang membuat fungsi dari pemecah gelombang (breakwater) tersebut tidak berfungsi dengan baik, maka harus dilakukan perbaikan terhadap pemecah gelombang (breakwater) oleh perusahaan kontraktor yang telah ditunjuk dan disetujui oleh club dan pertamina. Pemilihan kontraktor pada insiden atau case ini sangat membutuhkan waktu dikarenakan pemilihan kontraktor tersebut harus sesuai dengan kriteria atau klasifikasi dan bekerja berdasarkan CSMS dari PT. Pertamina. Dalam pemilihan tersebut menemukan hasil bahwa PT. Gillar Jaya sesuai dengan klasifikasi dari PT. Pertamina untuk melakukan perbaikan dengan pengawasan yang dilakukan oleh pihak Pertamina Kelautan IV Divisi Teknik dalam proses perbaikan sesuai dengan hasil dan kontrak kerja di atas. Perbaikan breakwater telah selesai diperbaiki pada tanggal 27 Maret 2018 dengan hasil pekerjaan 100 persen. Dokumentasi hasil perbaikan breakwater terlampir dan penerimaan serta rilis pernyataan telah ditandatangani pada tanggal 10 April 2018, perbaikan breakwater ini bekerja telah selesai secara hukum dan pemilik breakwater puas dengan pekerjaan perbaikan dan hasil dari perusahaan kontraktor dan pemilik.

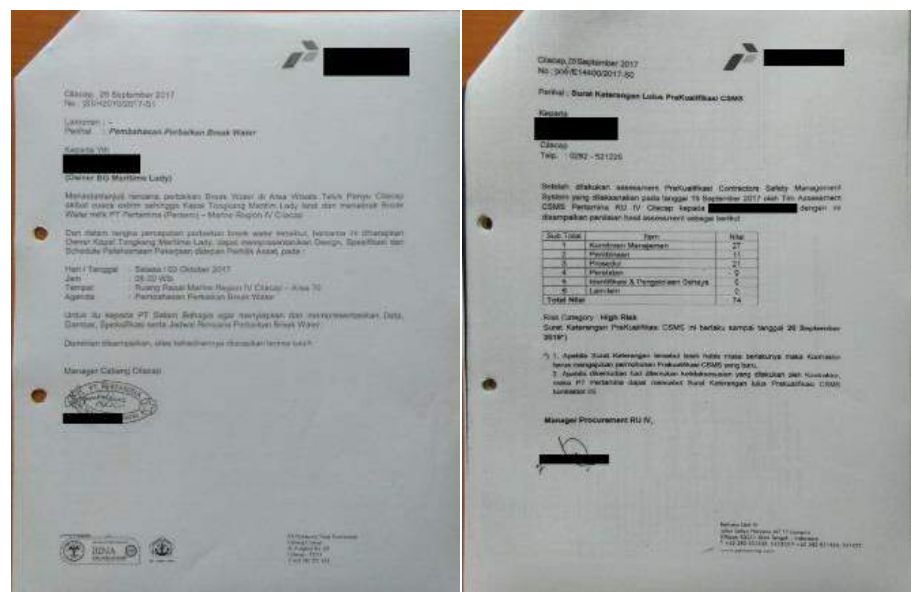

Gambar Surat Pemilihan Perusahaan Kontraktor Sumber : PT. Spicaputra Sarana (SPICA Service) Indonesia

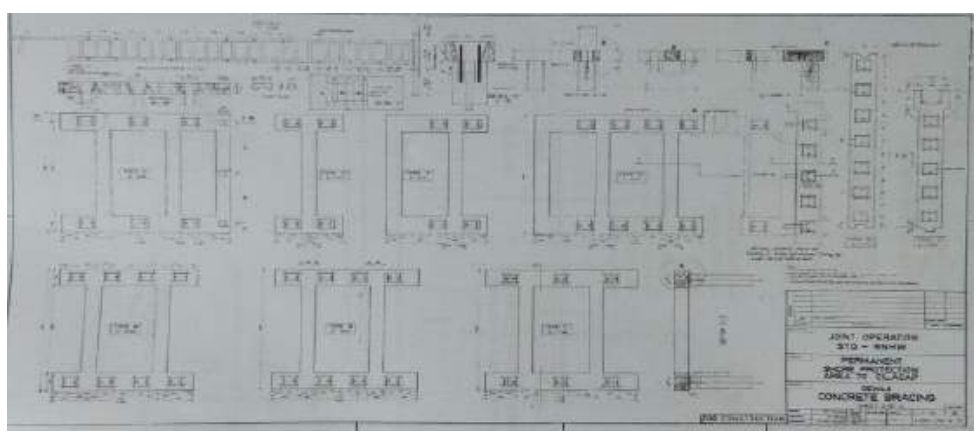

Gambar Struktur dan Konstruksi Breakwater Sumber : PT. Gillar Jaya dan PT. Pertamina 
3. Faktor ekonomi sosial dan cuaca (bad weather)

Dalam proses investigasi dan proses perbaikan pemecah gelombang (breakwater) yang dilakukan mengalami kendala yang disebabkan oleh faktor ekonomi sosial dari masyarakat sekitar daerah tersebut yang bergantung dengan fungsi dari pemecah gelombang (breakwater) sebagai tempat pariwisata dan tempat pekerjaan bagi mereka telah rusak dan terganggu dikarenakan breakwater tersebut rusak serta keadaan cuaca yang tidak mendukung dalam melaksanakan perbaikan pemecah gelombang (breakwater) tersebut akan tetapi proses perbaikan harus tetap dilaksanakan sebagaimana fungsi dari pemecah gelombang (breakwater) dan sesuai dengan perjanjian perbaikan. Oleh karena itu PT. Gillar Jaya dan operator kapal melakukan dialog persuasif dengan masyarakat sekitar untuk mempermudah proses perbaikan serta pihak operator atau pemilik kapal memberikan santunan biaya sebagai pengganti akibat terjadinya insiden atau case tersebut. PT. Gillar Jaya melakukan kerjasama dengan BMKG Cilacap untuk mengawasi prakiraan cuaca serta mendapat pengawasan pekerjaan dari Pertamina Kelautan IV agar tetap bekerja supaya struktur dan fungsi dari pemecah gelombang (breakwater) tersebut kembali normal sebagai tempat pekerjaan masyarakat sekitar dan tempat pariwisata di Teluk Penyu Cilacap.

\section{KESIMPULAN}

Berdasarkan penelitian yang telah dilakukan oleh peneliti tentang proses dan penyelesaian klaim asuransi kecelakaan kapal BG. Maritime Lady yang menabtrak breakwater Teluk Penyu Cilacap, maka peneliti dapat menarik kesimpulan sebagai berikut:

1. Proses pengajuan dan penyelesaian klaim asuransi kecelakaan kapal BG. Maritime Lady yang menabrak breakwater Teluk Penyu Cilacap yaitu tahapan pelaporan atau pemberitahuan pertama terlambat kepada P \& I Club oleh pemilik atau operator kapal yang membuat proses dan penyelesaian klaim memakan waktu lama.

2. Kendala-kendala yang dihadapi dalam proses dan penyelesaian klaim asuransi kecelakaan kapal BG. Maritime Lady oleh penanggung P \& I Club (The Shipowner's Insurance) terhadap tertanggung dan oleh surveyor independen adalah kelengkapan dokumen klaim yang belum lengkap seperti dokumen kepemilikan atau ahli waris dan data kontruksi dari pemecah gelombang (breakwater), pemilihan perusahaan kontraktor dalam perbaikan pemecah gelombang (breakwater) harus sesuai dengan klasifikasi dari PT. Pertamina, dan sosial ekonomi masyarakat sekitar serta keadaan cuaca yang tidak menentu atau tidak mendukung dalam perbaikan pemecah gelombang (breakwater).

3. Upaya yang dilakukan dalam menangani proses dan penyelesaian klaim asuransi kecelakaan kapal yaitu melakukan penelitian dan pemeriksaan dokumen kepemilikan pemecah gelombang (breakwater), memilih perusahaan kontraktor dalam membantu proses perbaikan, melakukan pendekatan persuasif dengan masyarakat berkaitan terhadap keadaan sosial ekonomi serta meninjau prakiraan cuaca.

\section{DAFTAR PUSTAKA}

Bambang Sumali, Tjahjono Eka Budi, dan Sukiman. 2018. Asuransi Maritime. Jakarta: Maritim Djangkar (Subdivisi EGC).

Capt. Martopo, Arso. 2012. Safety of Navigation \& Collision Regulation. Jakarta: Sekolah Tinggi Ilmu Pelayaran.

Ditjen Hubla. 2007. Materi Sosialisasi Pemeriksaan Kecelakaan Kapal. Jakarta. 
Analisa Pengurusan Proses Klaim Asuransi Kecelakaan Kapal Yang Menabrak Breakwater, Studi Kasus BG. Maritime Lady Di Teluk Penyu Cilacap

Winarno $^{\text {a }}$,Wim Benhard Manurung ${ }^{\mathrm{b}}$

Komite Nasional Keselamatan Transportasi. 2009. Kajian Analisis Trend Kecelakaan Transportasi Laut Tahun 20032008. Jakarta.

Kitab Undang-Undang Hukum Dagang Bab VI Tubrukan Kapal (Pasal 534-544a).

Nazir, M. 2014. Metode Penelitian. Jakarta: Ghalia Indonesia.

Nasution, S. 2014. Panduan Penuntun Tesis, Skripsi, Disertasi, Makalah. Jakarta: Bumi Aksara.

RH. Brown. A.C.I.I. M.Inst.A.M. 4 th Edition. 1962. Dictionary of Marine Insurance Terms.

Sugiyono. 2014. Metode Penelitian Kuantitatif, kualitatif, dan $R \& D$. Bandung: Alfabeta.

Sugiyono. 2015. Metode Penelitian Kuantitatif, kualitatif, dan $R \& D$. Bandung: Alfabeta.

Sugiyono. 2016. Metode Penelitian Kuantitatif, kualitatif, dan $R \& D$. Bandung: Alfabeta.

Sulaiman, Dede M. 2018. Beton dan Teknologi Pracetak pada Bangunan Pengamanan Pantai. Yogyakarta: CV. Budi Utama.

Timotius Kris H. 2017. Pengantar Metodologi Penelitian. Yogyakarta: CV. Andi Offset.

Umam Khotibul. 2014. Memahami \& Memilih Produk Asuransi. Yogyakarta: Medpress Digital.

Undang-Undang Republik Indonesia No 17 Tahun 2008 Tentang Pelayaran, Lembaran Negara No 64, Tahun 2008. 